\title{
Corticotropin-releasing factor (CRF) system localization in human fetal heart
}

\author{
Efterpi Chouridou, ${ }^{1}$ Maria Lambropoulou, ${ }^{2}$ Maria Koureta, ${ }^{1}$ Christina Zarouchlioti, ${ }^{1}$ \\ Ioanna Balgouranidou, ${ }^{1}$ Evangelia Nena, ${ }^{3}$ Nikolaos Papadopoulos, ${ }^{2}$ Ekaterini Chatzaki ${ }^{1}$ \\ ${ }^{1}$ Laboratory of Pharmacology, ${ }^{2}$ Laboratory of Histology-Embryology, ${ }^{3}$ Laboratory of Hygiene and Environmental Protection, \\ Faculty of Medicine, Democritus University of Thrace, Dragana, Alexandroupolis, Greece
}

\begin{abstract}
OBJECTIVE: The corticotropin-releasing factor (CRF) family consists of the neuropeptides CRF, Ucn I, II and III and the binding sites CRFR1, CRFR2 and CRF-BP. It regulates stress response and the homeostasis of an organism. In this study, we examined the presence of the CRF system in the human hearts of normal and pathological fetuses. DESIGN: Heart tissues from 40 archival human fetuses were divided into Group A (without pathology, 'normal'), Group B (with chromosomal abnormalities) and Group C (with congenital disorders). Immunohistochemistry was used to localize the CRF system. Results correlated to gestational trimester and pathology. RESULTS: Immunoreactivity for all antigens was found in cardiac myocytes of all groups, in almost all samples, except Ucn III which was present in almost half of the fetuses of Groups B and C and was not detected at all in Group A. Ucn III was more often present during the earlier stage of development ( $<21$ weeks) and in fetuses with congenital disorders. In a fetus diagnosed with heart pathology, all but Ucn III antigens were also present. CONCLUSIONS: We localized a complete CRF system in the human fetal heart and correlated the presence of Ucn III to development and pathology. More studies are needed to verify and clarify the exact role of the CRF system in the human fetal heart.
\end{abstract}

Key words: CRF, CRF receptors, Development, Fetal, Heart, Human, Urocortins

\section{INTRODUCTION}

Harris was the first to suggest that the hypothalamus regulates the secretion of the adrenocorticotropic hormone (ACTH) via neurochemical factors. ${ }^{1}$ His

\footnotetext{
Address for correspondence:

Dr. Ekaterini Chatzaki, Laboratory of Pharmacology, Faculty of Medicine, Democritus University of Thrace, Dragana, Alexandroupolis, P.C. 68100, Greece;

Tel./Fax: +30 25510 30533, E-mail: achatzak@med.duth.gr

Received: 11-06-2015, Accepted: 22-12-2015
}

theory was documented experimentally in the fifties by Saffran ${ }^{2}$ and was proven by Vale et al much later ${ }^{3}$ when a 41 amino acid peptide was isolated from the ovine hypothalamus. This peptide was originally named corticotropin-releasing hormone (CRH) and later corticotropin-releasing factor (CRF) by R. Hauger, ${ }^{4}$ since the functions of the specific peptide were beyond those of a simple hormone. Today we refer to the CRF system or family, which consists of the endogenous neuropeptides CRF, Urocortin I (Ucn I, 40 aa peptide), Urocortin II (Ucn II or stresscopin- 
related peptide, 38 aa) and Urocortin III (Ucn III or stresscopin, 38 aa), the receptors CRFR1 (415-446 aa) and CRFR2 (both belonging to the class B/secretin family of G-protein coupled receptors and both presenting various isoforms) and the CRF-binding protein (CRF-BP, a glycoprotein of 37-kDa with 322 aa). All neuropeptides bind with CRFR2, while Ucn II and III have moderate or no correlation with CRF-BP and CRFR1. ${ }^{5-8}$

In general, the CRF system is responsible for homeostasis ${ }^{9}$ and stress response regulation at multiple levels (neuronal, endocrine and immunological), while it is additionally connected to the phenomena of inflammation ${ }^{10}$ and apoptosis. ${ }^{11-15} \mathrm{CRF}$ system members are detected at multiple sites of the central nervous system (CNS) and in the periphery. A significant number of published studies have documented an important role of the CRF system within the cardiovascular system. ${ }^{16-24}$ In the adult heart, CRF and/or its ligands have been found to be expressed in both animals and humans. More specifically, they were identified in the heart of rodents, ${ }^{25}$ including rats ${ }^{26,18}$ and mice, ${ }^{21} \operatorname{dogs}^{27}$ and Tupaia belangeri. ${ }^{28}$ In adult humans on the other hand, an immunohistochemical study revealed Ucn I immunoreactivity in myocytes of the normal heart, which was more intense in the diseased heart, indicating, together with evidence of its positive inotropic action, its possible role in the pathophysiology of cardiac hypertrophy or the failing heart. ${ }^{11}$ In addition, Ucn II transcripts were detected at high levels of expression in human heart tissues. ${ }^{6}$ According to another study, Ucn I is produced in the human heart, where it is stored, and can exert its effects via CRF-R2 in an autocrine and/or paracrine way. ${ }^{29}$

Interestingly, Baigent supported the view that since the adult heart secretes Ucn I, most probably the respective fetal tissue should also secrete the same neuropeptide. ${ }^{30}$ However, so far there has been no confirmation of the presence of the CRF family in the fetal heart of animals or humans. In the human, limited information is offered regarding the presence of the CRF system in fetal tissues and its contribution to fetal maturation and/or pathology. Recently we reported the presence of all CRF family members in human fetal lungs during development, ${ }^{31}$ while CRFR1 mRNA had previously been found in human fetal adrenals. ${ }^{32}$ In animal fetal tissues, studies have reported the presence of CRF family members centrally in the rat and ovine hypothalamus, ${ }^{33,34}$ in the ovine pituitary, ${ }^{35}$ hippocampal-amygdala complex, frontal cerebral cortex (FCC) and brainstem ${ }^{36}$ and in the mouse cerebellum. ${ }^{37}$ In the periphery, the CRF family was detected in the rat fetal pancreas and GI tract $^{38}$ and in the fetal ovine ${ }^{39}$ and sheep colon. ${ }^{40}$

In the present study, we examined by immunohistochemistry the presence of CRF neuropeptides and their binding sites in the heart of human fetuses. Our samples were obtained following spontaneous abortions and curettages and are representative of different gestational ages and pathology, including congenital or chromosomal disorders. Of these, a case study of a fetus diagnosed with heart pathology is presented separately.

\section{MATERIALS AND METHODS}

\section{Tissues}

Fetal heart tissues were retrieved from 40 archival human fetuses in the Histology-Embryology Laboratory Tissue Bank of the Democritus University of Thrace (DUTH), Alexandroupolis, Greece. All standard pathological examination and diagnosis data concerning the fetuses were available, as well as all relevant medical information on the mothers. All fetuses were derived from spontaneous abortions and curettages due to medical reasons involving the mother (elective therapeutic termination of pregnancy). Fetuses with nuchal cord were excluded from our study. Fetuses with no congenital or chromosomal anomalies and no signs of chorioamnionitis were considered as 'normal' (Group A, total $\mathrm{n}=15$, all male). Pathological fetuses were divided into two groups: Group B (total $n=4$, male:2, female: 2) included fetuses with chromosomal abnormalities (Down syndrome and Edward's syndrome) and Group C (total $n=21$, male: 13 , female:8) with congenital malformations (of the Nervous System, heart/central vessels, lungs, skeleton, abdominal wall, visceral cranium and face). It is important to note that some of the fetuses suffered from more than one pathology, as can be seen in Table 1. Fetuses were further divided into gestational trimesters, according to their gestational age, which ranged from 12 to 39 weeks and was estimated by the mother's last menstrual period (LMP). The first 12 weeks of 
Table 1. Characteristics and grouping of fetuses used in the study (Some of the pathological fetuses suffered from more than one pathology). Gestational age was estimated by mother's last menstrual period (LMP)

\begin{tabular}{|c|c|c|c|c|c|c|c|}
\hline \multirow[t]{3}{*}{ Group } & \multicolumn{6}{|c|}{ Number of fetuses (n) } & \multirow[t]{3}{*}{ Pathology } \\
\hline & \multirow[t]{2}{*}{ Total } & \multicolumn{3}{|c|}{ Gestational trimester } & \multicolumn{2}{|c|}{ Sex } & \\
\hline & & First & Second & Third & Male & Female & \\
\hline A & 15 & 0 & 13 & 2 & 15 & 0 & No pathology \\
\hline B & 4 & 0 & 3 & 1 & 2 & 2 & Chromosomal abnormalities \\
\hline $\mathrm{C}$ & 21 & 1 & 15 & 5 & 13 & 8 & Congenital disorders \\
\hline $\mathrm{A}+\mathrm{B}+\mathrm{C}$ & 40 & 1 & 31 & 8 & 30 & 10 & \\
\hline
\end{tabular}

Group A: fetuses with no pathological findings were considered 'normal'. Group B: pathological fetuses with chromosomal abnormalities. Down syndrome $(n=3)$, Edward syndrome $(n=1)$, acute non-specific chorioamnionitis $(n=1)$, hydropic degeneration of chorionic villi $(n=1)$. Group $C$ : pathological fetuses with congenital disorders of visceral cranium/face $(n=6)$, skeleton $(n=3)$, heart/central vessels $(\mathrm{n}=1)^{*}$, lungs $(\mathrm{n}=2)$, nervous system $(\mathrm{n}=7)$ and abdominal wall $(\mathrm{n}=1)$. Two fetuses suffered from hydropic degeneration of chorionic villi, 8 from acute chorioamnionitis, 2 from acute placentitis, 2 from recessive fetal development and 1 from oligohydramnios. *Heart pathology: presence of interventricular foramen, right ventricle hypertrophy and aortic translocation astride the interventricular septum.

pregnancy were considered as the first trimester, the period between the $13^{\text {th }}$ and $24^{\text {th }}$ gestational week the second trimester and beyond the $25^{\text {th }}$ gestational week the third trimester. Following the classification of the fetuses, an autopsy was performed and heart tissues were obtained from the right or left fetal ventricle. The tissues were finally embedded in paraffin and sections were used for immunohistochemistry. The study protocol was approved by the Ethical Committee of the University Hospital of DUTH, (Decision no. $45 / 27^{\text {th }} / 16-11-2009$ ) and was conducted according to the guidelines for the analysis of fetal cells and tissues.

\section{Antisera}

The antisera used for CRF, CRFR2, Ucn I, II and III detection were obtained from Phoenix Pharmaceuticals (H-017-06, H-006-24, H-019-14, H-019-30, H-019-28, respectively; Belmont, Calif., U.S.A.). The antiserum used for CRF was raised against the whole human peptide sequence: it is $100 \%$ specific for human, rat, mouse, canine and feline CRF and exhibits no crossreactivity to other peptides. The specific antiserum used for CRFR2 was raised against aa 385-411 of the human CRFR2 receptor. The specific antiserum used for Ucn I was raised against the whole human Ucn I peptide sequence and is $100 \%$ specific for human and rat peptide. The specific antiserum used for Ucn II was raised against aa 6-43 of the human Ucn II peptide sequence. The specific antiserum used for Ucn III was raised against aa 3-40 of the human Ucn
III peptide sequence. The CRF-BP antiserum was obtained from Santa-Cruz Biotechnology [CRF-BP (C-8): SC-365975]: it is a mouse monoclonal antibody specific for an epitope mapping between amino acids 299-322 at the C-terminus of CRF-BP of human origin. The anti-CRFR1 antiserum was the IgG-purified fraction of 4467a-CRFR1 which has previously been shown to be specific and selective for CRFR1..$^{41,42}$ It was kindly donated by Dr. D. Grigoriadis, Neurocrine Bioscience Inc., San Diego, CA., U.S.A.

\section{Immunohistochemistry}

Immunohistochemistry was conducted as previously described. ${ }^{43}$ Tissue specimens were fixed in formalin and embedded in paraffin, according to standard procedures. Four-micron sections $(4 \mu \mathrm{m})$ of representative blocks were deparaffinized, rehydrated and treated with $0.3 \% \mathrm{H}_{2} \mathrm{O}_{2}$ for $5 \mathrm{~min}$ in methanol to prevent endogenous peroxidase activity. After washing, slides were incubated at $4^{\circ} \mathrm{C}$ overnight with the primary rabbit anti-human polyclonal antiserum (antiCRF 1:500, anti-Ucn I 1:500, anti-Ucn II 1:1000, antiUcn III 1:4000, anti-CRF-BP 1:200, 4467a-CRFR1 1:7000, anti-CRFR2 1:1000, diluted in 10\% normal rabbit serum in phosphate buffer saline, PBS). Control slides were incubated for the same period with normal rabbit serum $\mathrm{IgG}$ and were used as common negative control for all antibody staining. Immunostaining was detected by the the Dako REAL TM EnVision TM Detection System, Peroxidase/DAB+, Rabbit/ 
Mouse kit (DAKO Denmark A/S, Denmark), using a standard streptavidin/biotin detection method, following the instructions of the manufacturer. Finally, bound antibody complexes were stained for $5 \mathrm{~min}$ with $0.05 \%$ diaminobenzidine, counterstained with Mayer's haematoxylin, mounted and observed under a Nikon Eclipse 50i microscope. The same process was followed for all the negative control slides.

For each slide, approximately 10 fields of stained sections were evaluated by two independent observers and scored in a blinded fashion. Estimations by the two independent observers had an approximately 10\% disagreement in most cases and was therefore considered insignificant. Every stained cell was scored as positive, regardless of its staining intensity. Positivity was graded in a four-scale system as follows: Grade 3 represents $>70 \%$ positive cells in the total number of cells of the specific cell-type counted per field, Grade 2 between $40-70 \%$, Grade 1 between $10-40 \%$ and Grade 0 stands for $<10 \%$ positively stained cells. The extent of positive cells was assessed in cardiac myocytes.

\section{Statistical analysis}

Statistical significance was assessed by the chisquare test for categorical variables using SPSS 17.0 statistical software (SPSS Inc. Chicago, Illinois, USA). Significance was set at $p$ value $<0.050$. Comparisons were made between positively stained (Grades 1, 2 and 3 ) and negative (Grade 0) tissues.

\section{RESULTS}

Cardiac myocytes were positively stained by immunohistochemistry for all antibodies, except Ucn III, which was not detected at all in Group A. Immunoreactivity was localized in the cell cytoplasm for all neuropeptides and CRF-BP, while for the receptors it was mainly membranic. Blood vessels and arteries were positive for all antibodies. Human placental tissue was also stained in parallel and was used as a positive control for all antigen staining (not shown). Representative pictures of fetuses of different gestational week, normal or pathological, are depicted in Figure 1. Accumulated results depicting fractions of positive tissues per study group are shown in Figure 2. Gestational age of fetuses was estimated by the mother's last menstrual period (LMP).

\section{Immunohistochemical localization of CRF neuropeptides and receptors in the human fetal heart}

Results for CRF, Ucn I, II and III, receptors CRFR1, CRFR2 and CRF-BP immunohistochemistry with semi-quantitative evaluation in the human fetal heart are presented in Tables 2, 3 and 4 and Figure 2. Immunolocalization of CRF, Ucn I, Ucn II, CRFR1, CRFR2 and CRF-BP was found at different grades in all groups and gestational trimesters of our fetus groups. CRF staining was strongly positive (Grade 3 ) in all fetuses for all Groups and trimesters. Likewise, Ucn I presence was moderately to strongly positive (Grade 2-3) in all fetuses. Ucn II was also present in all but one tissue (female fetus, $20 \mathrm{w}$, with congenital disorders of visceral cranium/face and acute chorioamnionitis), in varying intensities (Grade 1-3, mostly 2). In contrast, Ucn III was weakly immunoreactive (Grade 1) in half of Group B fetuses and in a few (38.09\%) of Group $\mathrm{C}$, while it was absent in all fetuses of Group A and in fetuses of the third gestational trimester. In fact, the presence of Ucn III was significantly correlated to gestational age, as it was more frequently found before the $21^{\text {st }}$ gestational week than in older fetuses $(p=0.021)$, whereas statistical analysis between the $2^{\text {nd }}$ and $3^{\text {rd }}$ trimester fetuses showed marginally no significance $(p=0.08)$. Presence of Ucn III was also correlated to the diagnosis of some kind of congenital disorder, as it was more often found in Group $\mathrm{C}$ than in Group A (normal fetuses) $(p=0.016)$.

The binding site study demonstrated (see also Figure 2) that CRFR1 was strongly stained (Grade 3) in all but one tissue of Group A, all tissues of Group $\mathrm{B}$, and was found moderately to strongly positive in Group C (Grade 2-3). CRFR2 was also present in all but one tissue of Group A, all tissues of Group B and all but two tissues (male fetus, $23 \mathrm{w}$, with congenital disorders of visceral cranium/face and female fetus, $27 \mathrm{w}$, with recessive fetal development) of Group C at varying intensities (Grade 1-3, mostly 2). CRFBP immunoreactivity was intense (Grade 3 ) in all fetuses of all Groups and trimesters. No correlation was found between CRF system presence and the presence of chorioamnionitis, maternal age and fetal sex, although the limitations due to the small number of tissues in some groups and sex equilibrium (Group A) hampered statistical analysis (see Table 1). 


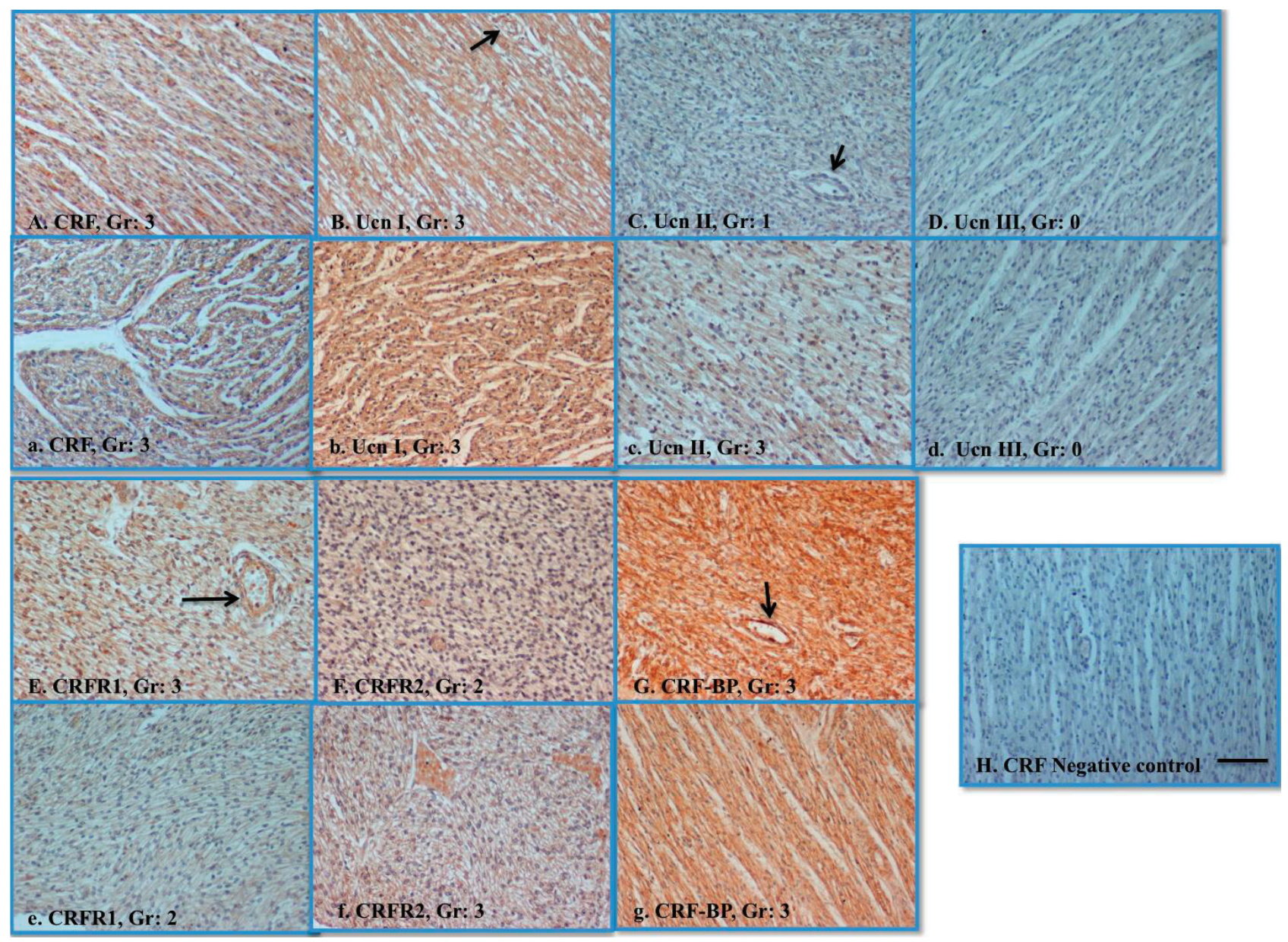

Figure 1. Immunohistochemistry for CRF neuropeptides and binding sites in heart tissues of human fetuses of different gestational trimesters, with or without diagnosed pathology. Grading (Gr) for the myocytes is shown. Some clearly positive vessels are also shown by arrows. A-G: fetuses with no diagnosed pathology from the second (B, C, E, F, G) and the third trimester (A, D). a-g: pathological fetuses from the first (c), second ( $a, b, e, f)$ and the third gestational trimester $(\mathrm{d}, \mathrm{g})$, diagnosed with various pathologies other than the heart. Gestational age was estimated by the mother's LMP. Original magnification: X200. Scale bar $=100 \mu$ m. H: negative control (third trimester fetus).

Grade 3: $>70 \%$ positive cells in the total number of cells of the specific cell-type counted per field.

Grade 2: 40-70\% positively stained cells.

Grade 1: $10-40 \%$ positively stained cells.

Grade 0: $<10 \%$ positively stained cells.

\section{Immunohistochemical localization of the CRF system in a fetus with heart pathology}

Among the Group $\mathrm{C}$ fetuses, there was one fetus diagnosed with heart pathology that is presented as a case study. Specifically, this fetus was female, 23 weeks old (second gestational trimester) and was suffering from the presence of an interventricular foramen, right ventricle hypertrophy and aortic translocation astride the interventricular septum (Figure 3). CRF, Ucn I, CRFR1 and CRF-BP presence was strongly positive
(Grade 3), while Ucn II was moderate (Grade 2) and CRFR2 weak (Grade 1). Ucn III was not detected in the heart tissue of this fetus. It is also noteworthy that in this specific fetus, receptor localization was both cytoplasmic and membranic.

\section{DISCUSSION}

Given the considerable interest in the role of the CRF system in cardiovascular phenomena and the total lack of available information on its presence in 

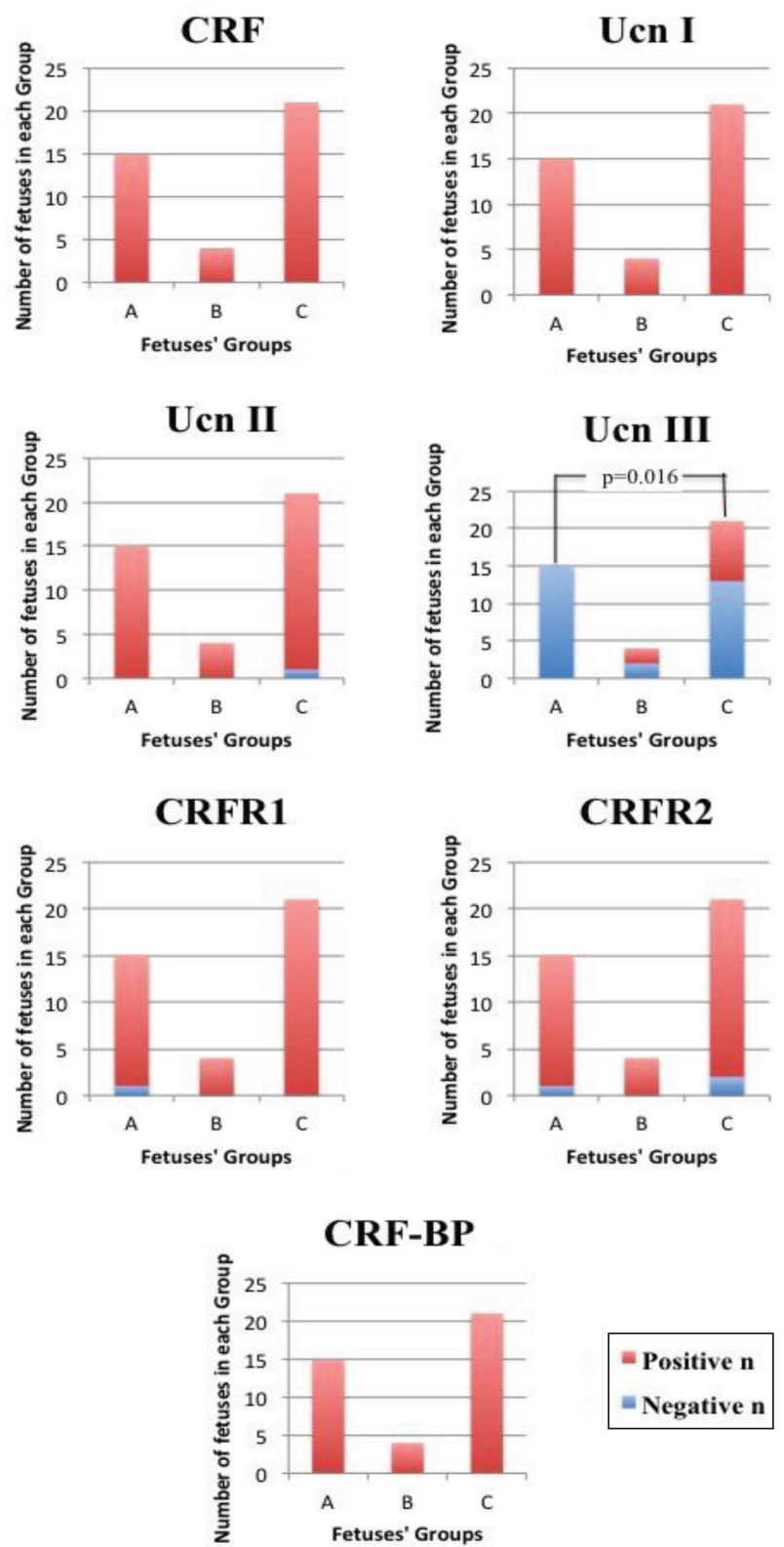

- Positive n

= Negative $\mathbf{n}$

Figure 2. Immunohistochemical detection of CRF neuropeptides and binding sites: accumulated data showing fractions of positively (red) and negatively (blue) stained fetal heart tissues. X-axis: A: Group A (fetuses with no pathology), B: Group B (pathological fetuses with chromosomal abnormalities), C: Group C (pathological fetuses with congenital disorders). Yaxis: Number of fetuses in each Group. A statistical difference between Groups and respective $\mathrm{p}$ value are shown. $\mathrm{n}=$ number of fetuses.

the fetal heart, this study aimed to describe the histological mapping of CRF neuropeptides and binding sites in the human fetal heart. Forty archival human fetuses, including fetuses without diagnosed pathology,
Table 2. Semi-quantitative estimation for the presence of CRF, Ucn I, II and III, CRFR1, CRFR2 and CRF-BP detected by immunohistochemistry in the myocytes of human fetal heart tissues. Numbers represent the number of fetuses in each of the four grades $(\mathrm{G})$, in every gestational trimester as estimated by the mother's last menstrual period (LMP), in the Group A (fetuses with no pathology)

\begin{tabular}{|c|c|c|c|c|}
\hline \multirow[t]{2}{*}{ Peptides } & \multirow[t]{2}{*}{ Grade } & \multicolumn{3}{|c|}{ Gestational trimester } \\
\hline & & $\begin{array}{c}\text { First } \\
\text { (Total n: } 0 \text { ) }\end{array}$ & $\begin{array}{c}\text { Second } \\
\text { (Total n: 13) }\end{array}$ & $\begin{array}{c}\text { Third } \\
\text { (Total } \mathrm{n}: 2 \text { ) }\end{array}$ \\
\hline \multirow[t]{4}{*}{ CRF } & G:0 & & & \\
\hline & G:1 & & & \\
\hline & G:2 & & & \\
\hline & G:3 & & 13 & 2 \\
\hline \multirow[t]{4}{*}{ Ucn I } & G:0 & & & \\
\hline & $\mathrm{G}: 1$ & & & \\
\hline & $\mathrm{G}: 2$ & & & 1 \\
\hline & G:3 & & 13 & 1 \\
\hline \multirow[t]{4}{*}{ Ucn II } & G:0 & & & \\
\hline & G:1 & & 5 & 2 \\
\hline & G:2 & & 6 & \\
\hline & G:3 & & 2 & \\
\hline \multirow[t]{4}{*}{ Ucn III } & G:0 & & 13 & 2 \\
\hline & $\mathrm{G}: 1$ & & & \\
\hline & $\mathrm{G}: 2$ & & & \\
\hline & $\mathrm{G}: 3$ & & & \\
\hline \multirow[t]{4}{*}{ CRFR1 } & G:0 & & 1 & \\
\hline & G:1 & & & \\
\hline & G:2 & & & \\
\hline & G:3 & & 12 & 2 \\
\hline \multirow[t]{4}{*}{ CRFR2 } & G:0 & & 1 & \\
\hline & $\mathrm{G}: 1$ & & 2 & 2 \\
\hline & $\mathrm{G}: 2$ & & 7 & \\
\hline & $\mathrm{G}: 3$ & & 3 & \\
\hline \multirow[t]{4}{*}{ CRF BP } & G:0 & & & \\
\hline & G:1 & & & \\
\hline & $\mathrm{G}: 2$ & & & \\
\hline & G:3 & & 13 & 2 \\
\hline
\end{tabular}

n: number of fetuses.

with chromosomal abnormalities or with congenital disorders were used and antigen localization was studied by immunohistochemistry. Our samples were representative of different gestational ages allowing developmental observations, although the small number of tissues in some groups (first trimester group) limited conclusions. Nevertheless, given the rarity 
Table 3. Semi-quantitative estimation for the presence of CRF, Ucn I, II and III, CRFR1, CRFR2 and CRF-BP detected by immunohistochemistry in the myocytes of human fetal heart tissues. Numbers represent the number of fetuses in each of the four grades $(G)$, in every gestational trimester as estimated by the mother's last menstrual period (LMP), in the Group B (fetuses with genetic disorders)

\begin{tabular}{|c|c|c|c|c|}
\hline \multirow[t]{2}{*}{ Peptides } & \multirow[t]{2}{*}{ Grade } & \multicolumn{3}{|c|}{ Gestational trimester } \\
\hline & & $\begin{array}{c}\text { First } \\
\text { (Total n: } 0)\end{array}$ & $\begin{array}{c}\text { Second } \\
\text { (Total n: 3) }\end{array}$ & $\begin{array}{c}\text { Third } \\
\text { (Total n: } 1)\end{array}$ \\
\hline \multirow[t]{4}{*}{ CRF } & $\mathrm{G}: 0$ & & & \\
\hline & G:1 & & & \\
\hline & $\mathrm{G}: 2$ & & & \\
\hline & G:3 & & 3 & 1 \\
\hline \multirow[t]{4}{*}{ Ucn I } & $\mathrm{G}: 0$ & & & \\
\hline & G:1 & & & \\
\hline & $\mathrm{G}: 2$ & & 1 & \\
\hline & $\mathrm{G}: 3$ & & 2 & 1 \\
\hline \multirow[t]{4}{*}{ Ucn II } & G:0 & & & \\
\hline & G:1 & & 2 & \\
\hline & $\mathrm{G}: 2$ & & 1 & 1 \\
\hline & $\mathrm{G}: 3$ & & & \\
\hline \multirow[t]{4}{*}{ Ucn III } & $\mathrm{G}: 0$ & & 1 & 1 \\
\hline & $\mathrm{G}: 1$ & & 2 & \\
\hline & $\mathrm{G}: 2$ & & & \\
\hline & $\mathrm{G}: 3$ & & & \\
\hline \multirow[t]{4}{*}{ CRFR1 } & $\mathrm{G}: 0$ & & & \\
\hline & G:1 & & & \\
\hline & $\mathrm{G}: 2$ & & & \\
\hline & $\mathrm{G}: 3$ & & 3 & 1 \\
\hline \multirow[t]{4}{*}{ CRFR2 } & G:0 & & & \\
\hline & G:1 & & & \\
\hline & $\mathrm{G}: 2$ & & 1 & \\
\hline & $\mathrm{G}: 3$ & & 2 & 1 \\
\hline \multirow[t]{4}{*}{ CRF BP } & $\mathrm{G}: 0$ & & & \\
\hline & G:1 & & & \\
\hline & $\mathrm{G}: 2$ & & & \\
\hline & $\mathrm{G}: 3$ & & 3 & 1 \\
\hline
\end{tabular}

n: number of fetuses.

of such sample availability, we considered these data worth presenting. Immunoreactivity for all antigens was found in cardiac myocytes of all groups, in almost all samples, at different levels, except Ucn III that was present in almost half of the fetuses with pathology (both chromosomal and congenital) but was not detected at all in normal fetuses. Ucn III was more
Table 4. Semi-quantitative estimation for the presence of CRF, Ucn I, II and III, CRFR1, CRFR2 and CRF-BP detected by immunohistochemistry in the myocytes of human fetal heart tissues. Numbers represent the number of fetuses in each of the four grades $(G)$, in every gestational trimester as estimated by the mother's last menstrual period (LMP), in the Group C (fetuses with congenital disorders)

\begin{tabular}{|c|c|c|c|c|}
\hline \multirow[t]{2}{*}{ Peptides } & \multirow[t]{2}{*}{ Grade } & \multicolumn{3}{|c|}{ Gestational trimester } \\
\hline & & $\begin{array}{c}\text { First } \\
\text { (Total n: 1) }\end{array}$ & $\begin{array}{c}\text { Second } \\
\text { (Total n: } 15)\end{array}$ & $\begin{array}{c}\text { Third } \\
\text { (Total n: 5) }\end{array}$ \\
\hline \multirow[t]{4}{*}{ CRF } & G:0 & & & \\
\hline & $\mathrm{G}: 1$ & & & \\
\hline & $\mathrm{G}: 2$ & & & \\
\hline & $\mathrm{G}: 3$ & 1 & 15 & 5 \\
\hline \multirow[t]{4}{*}{ Ucn I } & G:0 & & & \\
\hline & $\mathrm{G}: 1$ & & & \\
\hline & $\mathrm{G}: 2$ & & & 1 \\
\hline & $\mathrm{G}: 3$ & 1 & 15 & 4 \\
\hline \multirow[t]{4}{*}{ Ucn II } & G:0 & & 1 & \\
\hline & $\mathrm{G}: 1$ & & 2 & 2 \\
\hline & $\mathrm{G}: 2$ & & 11 & 3 \\
\hline & $\mathrm{G}: 3$ & 1 & 1 & \\
\hline \multirow[t]{4}{*}{ Ucn III } & G:0 & & 8 & 5 \\
\hline & G:1 & 1 & 7 & \\
\hline & $\mathrm{G}: 2$ & & & \\
\hline & $\mathrm{G}: 3$ & & & \\
\hline \multirow[t]{4}{*}{ CRFR1 } & G:0 & & & \\
\hline & G:1 & & & \\
\hline & $\mathrm{G}: 2$ & & 6 & \\
\hline & $\mathrm{G}: 3$ & 1 & 9 & 5 \\
\hline \multirow[t]{4}{*}{ CRFR2 } & G:0 & & 1 & 1 \\
\hline & G:1 & & 3 & \\
\hline & $\mathrm{G}: 2$ & & 7 & 2 \\
\hline & $\mathrm{G}: 3$ & 1 & 4 & 2 \\
\hline \multirow[t]{4}{*}{ CRF BP } & G:0 & & & \\
\hline & G:1 & & & \\
\hline & $\mathrm{G}: 2$ & & & \\
\hline & $\mathrm{G}: 3$ & 1 & 15 & 5 \\
\hline
\end{tabular}

n: number of fetuses.

often present during the first stages of development and in fetuses with congenital disorders. Among fetuses with pathology there was one fetus diagnosed with heart pathology and it is presented as a case study, revealing the presence of all but Ucn III CRF system antigens. Logistic regression models for the exploration of possible predictors of the presence 


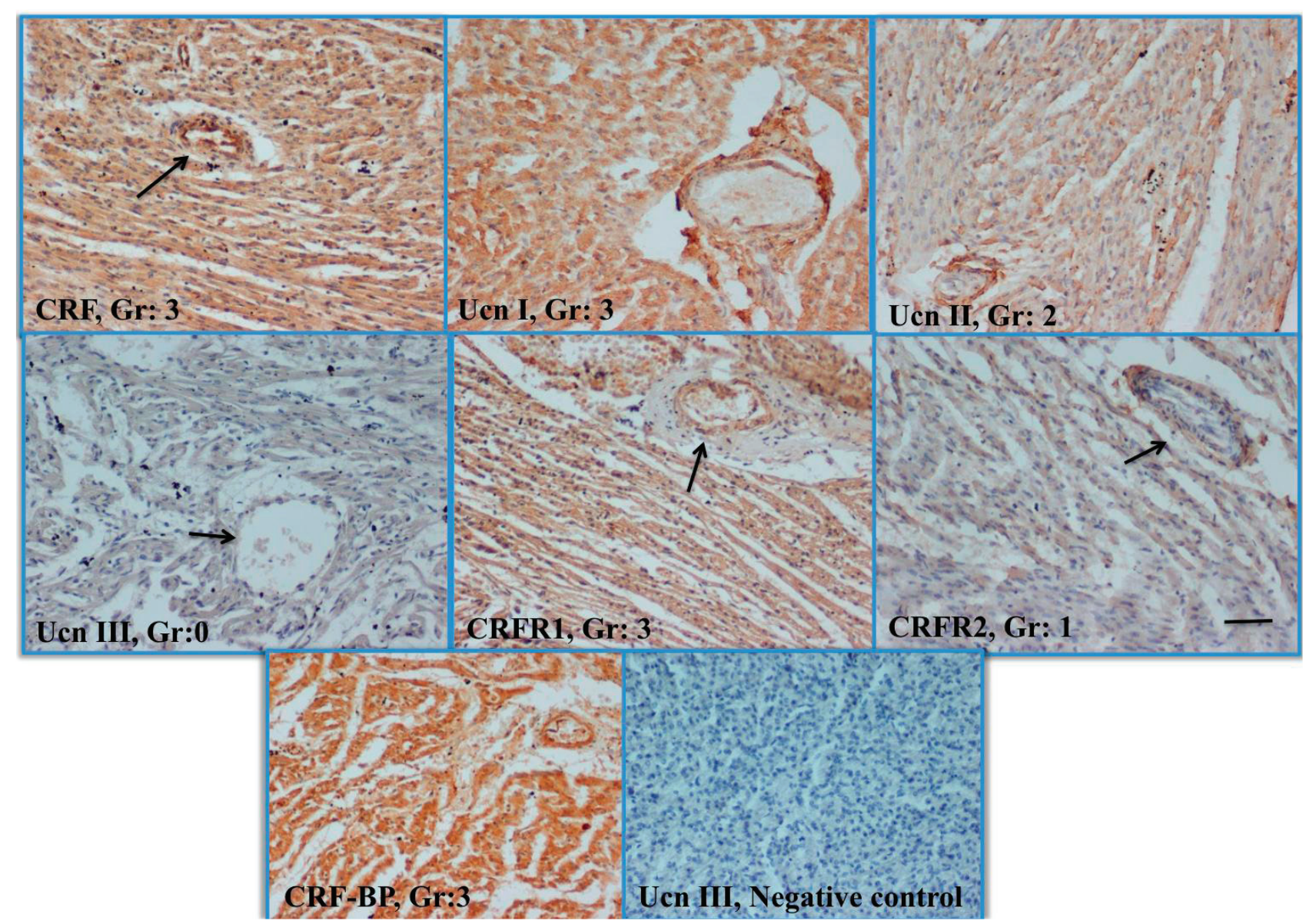

Figure 3. Immunohistochemistry for CRF neuropeptides and binding sites in the heart tissue of a fetus (female, 23 gestational weeks), diagnosed with heart pathology (presence of interventricular foramen, right ventricle hypertrophy and aortic translocation astride the interventricular septum). Grading (Gr) for the myocytes is shown. Some clearly positive vessels are also shown by arrows. Gestational age was estimated by the mother's LMP. Original magnification: $\times 200$. Scale bar: $100 \mu \mathrm{m}$. Grade $3:>70 \%$ positive cells in the total number of cells of the specific cell-type counted per field. Grade 2: 40-70\% positively stained cells. Grade 1: 10-40\% positively stained cells. Grade 0: $<10 \%$ positively stained cells.

of each factor were not applicable due to the size of our sample, which did not comply with the criteria set by Green SB. ${ }^{44}$ The results presented show for the first time the presence of the full CRF system, both neuropeptides and binding sites, in the human fetal heart. This is not surprising, as the presence of CRF neuropeptides ${ }^{6,11}$ and receptors ${ }^{29}$ has previously been shown in the human adult heart. Moreover, we have recently demonstrated the full CRF system localization in the lungs of normal and pathological human fetuses ${ }^{31}$ and suggested a possible role in its development.

CRF and CRF-BP immunoreactivity was strongly positive (Grade 3), while Ucn I presence was moder- ately to strongly positive (Grade 2-3) in all fetuses of all Groups and trimesters. It is well established that CRF and Ucn I bind to CRF-BP with higher affinity than to the other binding sites of the CRF system, thus their co-expression points to CRF-BP as a local regulator of their bioavailability. ${ }^{45}$

A previous study using in situ hybridization in order to evaluate CRF mRNA in the rat thorax ${ }^{46}$ evidenced expression during embryonic days 12 to 16 , peaking on the $14^{\text {th }}$ day, and located especially in the serous membranes, such as the pericardium. The researchers concluded that CRF must play a crucial role in the development of the pericardium. This is also corroborated by our results, although interspe- 
cies comparisons to our study cannot be made, as rat embryonic days 12-16 correspond to 28-52 weeks in humans and our sample comprises fetuses of 12-39 weeks of gestation.

Among the fetuses with congenital disorders of our study there was a fetus that was diagnosed with heart pathology. Specifically, this fetus was female, 23 weeks ( $\left({ }^{\text {nd }}\right.$ gestational trimester) and suffered from the presence of an interventricular foramen, right ventricle hypertrophy and aortic translocation astride the interventricular septum (Figure 2). In this fetus, CRF, Ucn I and CRFR1 presence was very strong, while Ucn II and III and CRFR2 were absent or weak. These findings could corroborate with other studies in mice, which have revealed the strong cardioprotective role of Ucn III, via CRFR2, and its smaller, parallel action on the hypothalamic stress axis, since it does not activate CRFR1. Ucn I plays also a cardioprotective role against ischemia reperfusion injury in mice when accompanied by CRFR2b; however, at the same time it activates CRFR1 in the pituitary gland, which causes activation of the hypothalamic stress axis and therefore complicates its possible use in the treatment of cardiovascular diseases. ${ }^{21,47}$ Furthermore, according to other researchers, ${ }^{18}$ Ucn I actions regulated by CRFR2 are mainly anti-inflammatory, most probably protecting cardiac myocytes from hypoxic death.

The strong Ucn I presence in the fetus of our study that suffered from right heart hypertrophy can also be correlated with the results of another study group: ${ }^{11}$ this showed that Ucn I was present in the cardiac myocytes of the left ventricle of normal adult human hearts and that this immunoreactivity was more intense in the left ventricle of a failing heart than of a normal heart. In addition, in rats with left heart hypertrophy due to DOCA-salt therapy, it was evident that Ucn I mRNA expression was higher, while CRFR $2 \beta \mathrm{m}$-RNA expression was significantly reduced compared to a normal left heart ventricle. The same research group concluded that although the mechanism of increased Ucn I mRNA expression or of increased Ucn I immunoreactivity in left heart hypertrophy or in the failing heart is still unknown, the importance of this fact seems to be correlated, at least partly, with the positive inotropic and hypertrophic action of Ucn I. Either way, the latter has been the main study subject of many other research groups. ${ }^{48,49}$ Moreover, Ikeda et al ${ }^{50}$ concluded that Ucn I is secreted not only by the cardiac myocytes but also by non-myocytes and that the primary source of Ucn I that acts on the heart is the heart itself. It was additionally proposed that Ucn I could lead to the proliferation of cardiac myocytes and non-myocytes, thereby causing hypertrophy and fibrosis.

Our results indicate that Ucn III may be more frequently present in embryos of younger gestational age, implying a role of Ucn III in development. In addition, its more frequent presence in fetuses with disorders of organs other than the heart could possibly indicate its involvement in impaired fetal growth. On the other hand, it could be the result of a recessive development, as it was not detected in the only fetus of our study that suffered from congenital disorders of the heart. In general, the changes in Ucn III in Groups B and C could represent a local protective mechanism to stressful stimuli, although we could not draw conclusions on whether the expression changes in the ligands and receptors is a compensatory rather than a causative mechanism. Further studies in larger groups could clarify its involvement in fetal development and pathology, especially as urocortins have recently been identified as a new group of inotropic factors with multiple and important effects on the cardiovascular, hemodynamic, neurohormonal and renal system ${ }^{51,52}$ and possibly novel players in the pathophysiology of the heart and its treatment.

In conclusion, our results present the histological mapping of the full CRF system, both neuropeptides and binding sites, in the heart of normal and pathological human fetuses, at different developmental stages. Although of weak clinical impact, we considered our findings of some importance given the rarity of this type of tissue availability. A more detailed study of the time-course of alterations of the CRF system in the fetal heart could promote a better understanding of its role given that the intracellular and/or organic conditions change dynamically through gestation. Its role in fetal development and fetal pathology awaits further investigation.

\section{ACKNOWLEDGMENTS}

We would like to thank Dr. D. Grigoriadis, Neurocrine Bioscience Inc., San Diego, Calif., U.S.A., for kindly providing the antisera for CRFR1. 
This research has been co-financed by the European Union (European Social Fund - ESF) and Greek national funds through the Operational Program "Education and Lifelong Learning" of the National Strategic Reference Framework (NSRF) - Research Funding Program: Heracleitus II. Investing in the knowledge society through the ESF.

\section{REFERENCES}

1. Harris GW, 1948 Neural control of the pituitary gland. Physiol Rev 28: 139-179.

2. Saffran M, Schally AV, 1955 The release of corticotropin by anterior pituitary tissue in vivo. Can J Biochem Physiol 33: 408-415.

3. Vale W, Spiess J, Rivier C, Rivier J, 1981 Characterization of a 41-residue ovine hypothalamic peptide that stimulates secretion of corticotropin and beta-endorphin. Science 213: 1394-1397.

4. Hauger RL, Grigoriadis DE, Dallman MF, et al, 2003 International Union of Pharmacology. XXXVI. Current Status of the Nomenclature for Receptors for Corticotropin-Releasing Factor and Their Ligands. Pharmacol Rev 55: 21-26.

5. Fekete EM, Zorrilla EP, 2007 Physiology, pharmacology, and therapeutic relevance of urocortins in mammals: ancient CRF paralogs. Front Neuroendocrinol 28: 1-27.

6. Hsu SY, Hsueh AJ, 2001 Human stresscopin and stresscopin-related peptide are selective ligands for the type 2 corticotropin-releasing hormone receptor. Nat Med 7: 605-611.

7. Lewis K, Li C, Perrin MH, et al, 2001 Identification of urocortin III, an additional member of the corticotropinreleasing factor (CRF) family with high affinity for the CRF2 receptor. Proc Natl Acad Sci USA 98: 7570-7575.

8. Reyes TM, Lewis K, Perrin MH, et al, 2001 Urocortin II: A member of the corticotropin-releasing factor (CRF) neuropeptide family that is selectively bound by type 2 CRF receptors. Proc Natl Acad Sci USA 98: 2843-2848.

9. Lovejoy DA, Balment RJ, 1999 Evolution and physiology of the corticotropin-releasing factor (CRF) family of neuropeptides in vertebrates. Gen Comp Endocrinol 115: 1-22.

10. Chatzaki E, Minas V, Zoumakis E, Makrigiannakis A, 2006b CRF Receptor Antagonists: Utility in Research and Clinical Practice. Curr Med Chem 13: 2751-2760.

11. Nishikimi T, Miyata A, Horio T, et al, 2000 Urocortin, a member of the corticotropin-releasing factor family, in normal and diseased heart. Am J Physiol Circ Physiol 279: H3031-3039.

12. Scarabelli TM, Pasini E, Ferrari G, et al, 2004 Warm blood cardioplegic arrest induces mitochondrial-mediated cardiomyocyte apoptosis associated with increased urocortin expression in viable cells. J Thorac Cardiovasc Surg 128: 364-371.
13. Chanalaris A, Lawrence KM, Stephanou A, et al, 2003 Protective effects of the urocortin homologues stresscopin (SCP) and stresscopin-related peptide (SRP) against hypoxia/reoxygenation injury in rat neonatal cardiomyocytes. J Mol Cell Cardiol 35: 1295-1305.

14. Chatzaki E, Lambropoulou M, Constantinidis TC, et al, 2006c Corticotropin-releasing factor (CRF) receptor type 2 in the human stomach: protective biological role by inhibition of apoptosis. J Cell Physiol 209: 905-911.

15. Paschos KA, Charsou C, Constantinidis TC, et al, 2010 Corticotropin-releasing hormone receptors mediate opposing effects in cholestasis-induced liver cell apoptosis. Endocrinology 151: 1704-1712.

16. Brown MR, Fisher LA, Spiess J, Rivier J, Rivier C, Vale W, 1982b Comparison of the biologic actions of corticotropin-releasing factor and sauvagine. Regul Pept 4: 107-114.

17. Parkes DG, Vaughan J, Rivier J, Vale W, May CN, 1997 Cardiac inotropic actions of urocortin in conscious sheep. Am J Physiol 272: H2115-2122.

18. Okosi A, Brar BK, Chan M, et al, 1998 Expression and protective effects of urocortin in cardiac myocytes. Neuropeptides 32: 167-171.

19. Bale TL, Contarino A, Smith GW, et al, 2000 Mice deficient for corticotropin-releasing hormone receptor-2 display anxiety-like behaviour and are hypersensitive to stress. Nat Genet 24: 410-414.

20. Brar BK, Jonassen AK, Railson J, et al, 2000 Urocortin protects against ischemic and reperfusion injury via a MAPK-dependent pathway. J Biol Chem 275: 85088514.

21. Brar BK, Jonassen AK, Egorina EM, et al, 2004 Urocortin-II and Urocortin-III are cardioprotective against ischemia reperfusion injury: an essential endogenous cardioprotective role for Corticotropin Releasing Factor Receptor Type 2 in the murine heart. Endocrinology 145: 24-35.

22. Venkatasubramanian S, Newby DE, Lang NN, 2010 Urocortins in heart failure. Biochem Pharmacol 80: 289-296.

23. Barry SP, Lawrence KM, McCormick J, et al, 2010 New targets of urocortin-mediated cardioprotection. J Mol Endocrinol 45: 69-85.

24. Smani T, Calderon E, Rodriguez-Moyano M, Dominguez-Rodriguez A, Diaz I, Ordóñez A, 2011 Urocortin-2 induces vasorelaxation of coronary arteries isolated from patients with heart failure. Clin Exp Pharmacol Physiol 38: 71-76.

25. Perrin MH, Vale WW, 1999 Corticotropin releasing factor receptors and their ligand family. Ann NY Acad Sci 885: 312-328.

26. Brar BK, Stephanou A, Okosi A, et al, 1999 CRH-like peptides protect cardiac myocytes from lethal ischaemic injury. Mol Cell Endocrinol 158: 55-63.

27. Veloso GF, Ohad DG, Francis AJ, et al, 2011 Expression of urocortin peptides in canine myocardium and plasma. Vet J 188: 318-324. 
28. Palchaudhuri MR, Hauger RL, Wille S, Fuchs E, Dautzenberg FM, 1999 Isolation and pharmacological characterization of two functional splice variants of corticotropin-releasing factor type 2 receptor from Tupaia belangeri. J Neuroen- docrinol 11: 419-428.

29. Kimura Y, Takahashi K, Totsune K, et al, 2002 Expression of urocortin and corticotropin-releasing factor receptor subtypes in the human heart. J Clin Endocrinol Metab 87: 340 -346.

30. Baigent SM, Lowry PJ, 2000 mRNA expression profiles for corticotrophin releasing factor (CRF), urocortin, CRF receptors and CRF-binding protein in peripheral rat tissues. J Mol Endocrinol 25: 43-52.

31. Chouridou E, Lambropoulou M, Koureta M, et al, 2014 A complete corticotropin releasing factor system localized in human fetal lung. Hormones(Athnes) 13: 229-243.

32. Sirianni R, Mayhew BA, Carr BR, Parker CR Jr, Rainey WE, 2005 Corticotropin-Releasing Hormone (CRH) and Urocortin Act through Type 1 CRH Receptors to Stimulate Dehydroepiandrosterone Sulfate Production in Human Fetal Adrenal Cells. J Clin Endocrinol Metab 90: 5393-5400.

33. Chatelain A, Boudouresque F, Chautard T, Dupouy JP, Oliver C, 1988 Corticotrophin-releasing factor immunoreactivity in the hypothalamus of the rat during the perinatal period. J Endocrinol 119: 59-64.

34. Maureen KW, Melanie JP, Jason AG, Nyima A, Charles E, 2006 Genomic analysis of neuroendocrine development of fetal brain-pituitary-adrenal axis in late gestation. Physiol Genomics 24: 218-224.

35. Green JL, Figueroa JP, Massmann GA, Schwartz J, Rose JC, 2000 Corticotropin-Releasing Hormone Type I Receptor Messenger Ribonucleic Acid and Protein Levels in the Ovine Fetal Pituitary: Ontogeny and Effect of Chronic Cortisol Administration. Endocrinology 141: 2870-2876.

36. Keiger CJ, O'Steen WK, Brewer G, Sorci-Thomas M, Zehnder TJ, Rose JC, 1995 Cortisol up-regulates corticotropin releasing factor gene expression in the fetal ovine brainstem at 0.70 gestation. Brain Res Mol Brain Res 32: 75-81.

37. King JS, Bishop GA, 2003 Localization of the type 1 corticotropin releasing factor receptor (CRF-R1) in the embryonic mouse cerebellum. J Neurocytol 32: 305-316.

38. Ohtsuka K, Koshimizu T, Ohyama Y, Yokota Y, 1986 The development of immunoreactive corticotropin-releasing factor (IR-CRF) in the hypothalamus, pancreas and gastrointestinal tract of immature rats. Nihon Naibunpi Gakkai Zasshi 62: 34-44.

39. Lakshmanan J, Magee TR, Richard JD, et al, 2008 Localization and gestation-dependent pattern of corticotrophin-releasing factor receptor subtypes in ovine fetal distal colon. Neurogastroenterol Motil 20: 1328-1339.

40. Lakshmanan J, Oyachi N, Ahanya SA, Liu G, Mazdak M, Ross MG, 2007 Corticotropin-releasing factor inhibition of sheep fetal colonic contractility: mechanisms to prevent meconium passage in utero. Am J Obstet Gynecol 196: 357.e1-7.

41. Chatzaki E, Crowe PD, Wang L, Million M, Taché Y, Grigoriadis DE, 2004a CRF receptor type 1 and 2 expression and anatomical distribution in the rat colon. J Neurochem 90: 309-316.

42. Chatzaki E, Murphy BJ, Wang L, et al, 2004b Differential profile of CRF receptor distribution in the rat stomach and duodenum assessed by newly developed CRF receptor antibodies. J Neurochem 88: 1-11.

43. Lambropoulou M, Papadopoulos N, Tripsianis G, et al, 2010 Co-expression of survivin, c-erbB2, and cyclooxygenase-2 (COX-2): prognostic value and survival of endometrial cancer patients. J Cancer Res Clin Oncol 136: 427-435.

44. Green SB, 1991 How many subjects does it take to do a regression analysis? Multivariate Behavioral Research 26: 499-510.

45. Behan DP, Heinrichs SC, Troncoso JC, et al, 1995 Displacement of corticotropin releasing factor from its binding protein as a possible treatment for Alzheimer's disease. Nature (London) 378: 284-287.

46. Imaki J, Onodera H, Yoshida K, Yamashita K, 1997 Expression of corticotropin-releasing factor (CRF) in peritoneum and pericardium in the rat embryo by in situ hybridization histochemistry. Peptides 18: 1243-1248.

47. Rademaker MT, Charles CJ, Espiner EA, et al, 2002 Beneficial hemodynamic, endocrine, and renal effects of urocortin in experimental heart failure: comparison with normal sheep. J Am Coll Cardiol 40: 1495-1505.

48. Gruson D, Ginion A, Lause P, Ketelslegers JM, Thissen JP, Bertrand L, 2012a Urotensin II and urocortin trigger the expression of myostatin, a negative regulator of cardiac growth, in cardiomyocytes. Peptides 33: 351-353.

49. Gruson D, Ginion A, Decroly N, et al, 2012b Urocortininduced cardiomyocytes hypertrophy is associated with regulation of the GSK-3 $\beta$ pathway. Heart Vessels 27: 202-207.

50. Ikeda K, Tojo K, Oki Y, Nakao K, 2002 Urocortin has cell-proliferative effects on cardiac non-myocytes. Life Sci 71: 1929-1938.

51. Garg V, Frishman WH, 2013 A new potential approach to inotropic therapy in the treatment of heart failure: urocortin. Cardiol Rev 21: 160-165.

52. Devetzis V, Zarogoulidis P, Kakolyris S, Vargemezis V, Chatzaki E, 2013 The Corticotropin Releasing Factor system in the kidney: perspectives for novel therapeutic intervention in nephrology. Medicinal Research Reviews 33: 847-872. 